\title{
Complete Recovery in Cryptogenic NORSE with Early Immunotherapy: A Case Report
}

\section{Erken İmmünoterapi ile Tam İyileşme Gözlenen Kriptojenik NORSE: Bir Olgu Sunumu}

\author{
(1) Türkan Acar, (1) Sena Boncuk, (1) Bilgehan Acar, (1) Yeşim Güzey Aras \\ Sakarya University Training and Research Hospital, Clinic of Neurology, Sakarya, Turkey
}

\begin{abstract}
The term new onset refractory status epilepticus (NORSE) is used for patients who do not have a history of seizures and a structural disorder and in whom no etiology can be found. Its treatment is very difficult and its mortality is high. In this article, we present a 62-year-old patient whose etiology was not elucidated despite all examinations and who was diagnosed as having NORSE. Full clinical improvement was achieved with corticosteroid treatment.
\end{abstract}

Keywords: NORSE, corticosteroid, status epilepticus

$\ddot{O} \mathbf{z}$

Yeni başlangıçlı refrakter status epileptikus (NORSE) tanımı, öncesinde nöbet öyküsü ve yapısal bir bozukluğu olmayan ve etiyolojik incelemelerde hiçbir sonuca ulaşılamayan klinik durumlar için kullanılmaya başlanan bir tanımlamadır. Tedavisi oldukça güç ve mortalitesi yüksektir. Bu yazıda 62 yaşında tüm incelemelere rağmen etiyolojisi aydınlatılamamış ve tedavide kortikosteroid uygulamasının tam yarar sağladığı, NORSE klinik tanısı ile takip edilen 62 yaşında bir hasta sunulmuştur.

Anahtar Kelimeler: NORSE, kortikosteroid, status epileptikus

\section{Introduction}

In $40 \%$ of patients with status epilepticus (SE), there is progression to refractory SE (RSE) and they often require intravenous (iv) anesthetic treatment and intensive care follow-up. However, RSE is still associated with significant morbidity and mortality (1).

The definition of new-onset RSE (NORSE) has started to find its place in the literature as a clinical condition that does not respond to first and second-line antiepileptic drugs (AEDs) in patients with no previously known epilepsy or any neurologic disorders (1,2). Febrile infection-related epilepsy syndrome (FIRES), which is defined as a subgroup of NORSE, is a clinical condition in which resistant seizures occur mostly in the the childhood age group 24 hours- 2 weeks after a febrile infection (3).

NORSE is a rare clinical picture rather than a specific diagnosis $(2,3,4,5)$. Autoimmune encephalopathy was found in $19 \%$ of the patients reported in the literature, and paraneoplastic encephalopathy was found in $18 \%$, and most remained cryptogenic (1). Although immunotherapy and ketogenic diet are recommended for treatment, the rate of poor clinical outcome is high (2). Moreover, there is not yet a clear guideline recommendation for the management and treatment of NORSE.

In this article, we present a 62-year-old female patient who had no previous diagnosis of epilepsy, who presented with SE with a clinical diagnosis of NORSE, and had complete recovery with early immunotherapy.

\section{Case Report}

A 62-year-old female patient was admitted to the emergency department with generalized tonic clonic seizures for the first time in her life. It was stated that she developed seizures after a few days of headache, restlessness, forgetfulness, and confusion. There was no history of any illness, drug use or toxic exposure. There was no feature in her family history. In the neurologic

Address for Correspondence/Yazışma Adresi: Türkan Acar MD, Sakarya University Training and Research Hospital, Clinic of Neurology, Sakarya, Turkey Phone: +904445400 E-mail: tdeniz38@hotmail.com ORCID: orcid.org/0000-0003-2001-914X

Received/Gelis Tarihi: 18.05 .2020 Accepted/Kabul Tarihi: 26.08.2020

${ }^{\circ}$ Copyright 2021 by Turkish Neurological Society

Turkish Journal of Neurology published by Galenos Publishing House. 
examination performed in the emergency department, the patient was in the postictal period, she was drowsy and her cooperation was limited. There was no neck stiffness. Cranial nerve and motor examination were evaluated as normal. Vital findings were stable, electrocardiography showed normal sinus rhythm, and her biochemistry and hemogram parameters were within the normal range. No central pathology was observed in the computed tomography, diffusion-weighted magnetic resonance imaging (MRI), contrast-enhanced MRI, and MR venography. Iv diazepam and valproic acid were given. Iv phenytoin treatment was added because there were recurrent seizures and there was no improvement in consciousness, and the patient was transferred to the neurology intensive care unit (ICU) with a diagnosis of SE.

Lumbar puncture (LP) was performed. The opening pressure was $12 \mathrm{~cm} \mathrm{H} \mathrm{H}_{2} \mathrm{O}$ in LP and no cells were detected. Cerebrospinal fluid (CSF) microprotein was $112 \mathrm{mg} / \mathrm{dl}$ (normal 15-45 mg/dl) and glucose $72 \mathrm{mg} / \mathrm{dl}$. Viral and bacterial meningitis panels were negative. On the second day of her admission, the patient's cranial MRI (Figure 1) was repeated, but no pathology was found. On the electroencephologram (EEG), slowing of the ground activity and several sharp wave discharges were observed (Figure 2). To explain the current encephalopathy, the patient's examinations were expanded. Thyroid-stimulating hormone, T3, T4 were in the normal range and anti-thyroglobulin and anti-thyroid peroxidase antibodies antibodies were negative. Vasculitis panel, TORCH, Brucella and VDRL test antibodies were negative. Ammoniak was in the normal range. Topiramate was added and gradually increased up to $4 \times 100 \mathrm{mg} /$ day because the seizures continued and her confusion did not improve.

All markers that could be checked for autoimmune encephalitis were negative (NMDAR, AMPA1, AMPA 2, CASPR 2, LGI1, GABARB1, VGKC), and 14-3-3 protein was negative, which was studied to exclude Creutzfeldt-Jakob disease.

The paraneoplastic panel studied for the pre-diagnosis of paraneoplastic autoimmune encephalitis was negative [amphiphysin, CV2, PNMA2 (Ma2/Ta), Ri, Yo, Hu, Recoverin, SOX1, Titin, Zic4, GAD65, Tr (DNER)]. The patient, whose confusion persisted and who developed agitation, was treated with iv methylprednisolone $1000 \mathrm{mg} /$ day due to the unexplained encephalopathy. The patient was given iv pulse steroid for 5 days, and the neurological examination started to improve from the second day of treatment. Confusion regressed and agitation improved. The pulse steroid treatment was switched to oral maintenance steroid therapy and the patient was discharged on the $14^{\text {th }}$ day. During the 6 -month follow-up after discharge, no symptoms or seizures were observed.
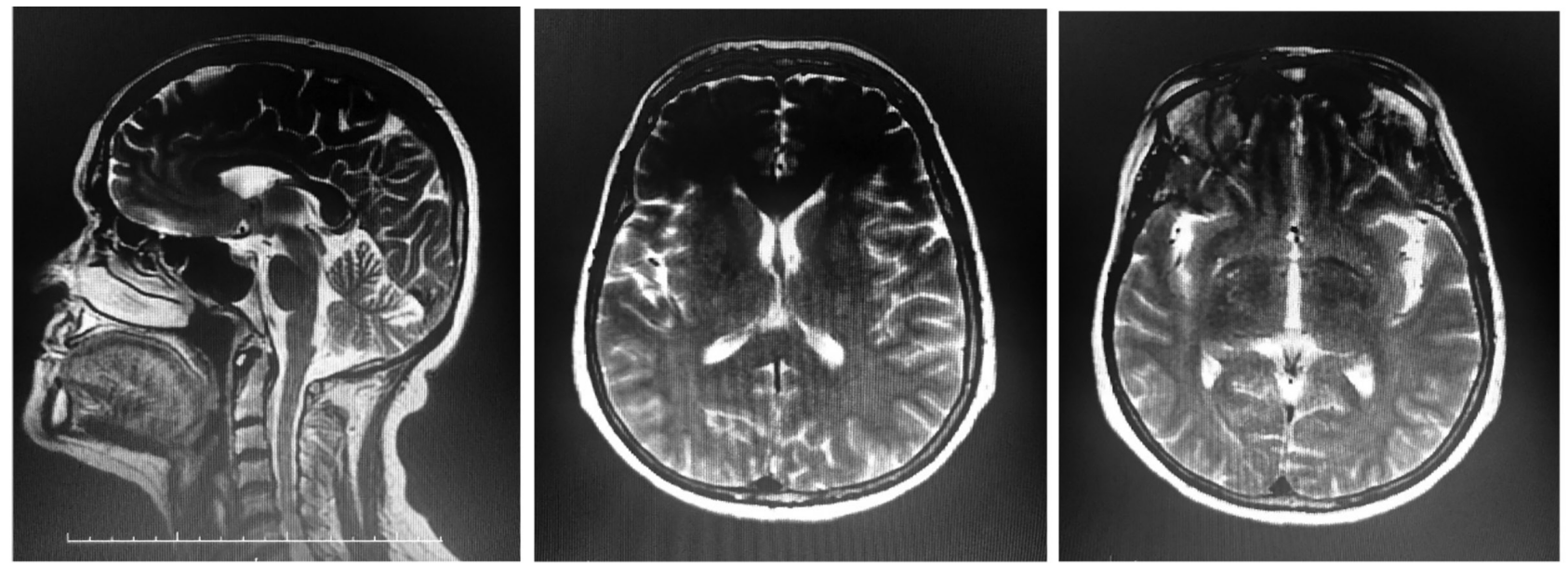

Figure 1. Cranial MRI within normal limits

MRI: Magnetic resonance imaging
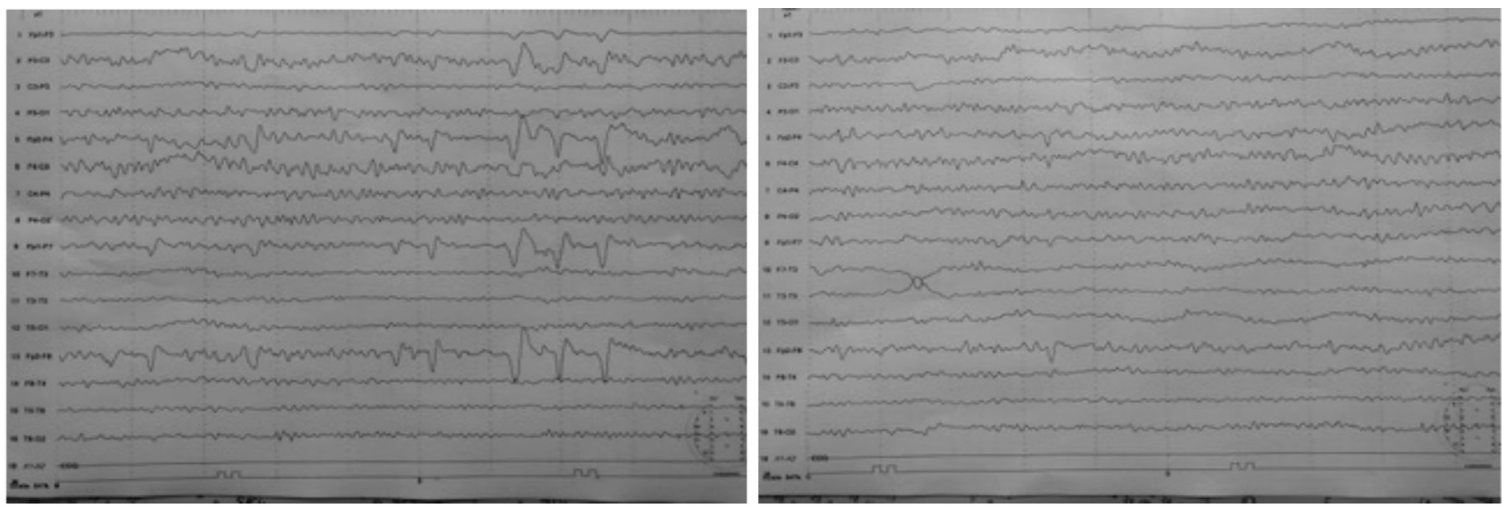

Figure 2. Slowing of ground activity and sharp and slow wave activity in both frontal regions 


\section{Discussion}

The terminology of NORSE is used for a patient without a previously known diagnosis of epilepsy or other pre-existing neurologic disorder, and it is a clinical entity that has no acute or active structural, toxic or metabolic cause, and does not respond to first and second-line AEDs (2). NORSE is a rare clinical condition. It was first presented by Wilder-Smith in a publication in which he retrospectively reported seven patients from his own clinic ge had followed in the last 3 years (4). Afterwards, there were case series reported from many parts of the world. None of the patients had a previous history of epilepsy. Some reported prodromal symptoms such as headache, fever and weakness 3 to 14 days before admission to the hospital with SE. However, it was reported that some patients were previously asymptomatic $(4,5,6)$. Although the average age was very different in the studies, the age range was accepted as $18-75$ years $(2,4,5)$. Although some of the reported patients were resistant to aggressive antiepileptic therapy, a complete recovery was found in some. Multiple EEG changes, CSF abnormalities, and in some patients hyperintensity in the leptomeninx and temporal lobe detected on MRI, were observed. However, there is no specific laboratory test or imaging method that can help in the diagnosis of the condition $(4,6)$. For differential diagnosis, all infectious, inflammatory, metabolic and toxic causes that may create a similar clinical picture should be excluded.

According to the latest definitions, the etiology of NORSE is either unknown or defined as an unusual cause despite extensive research.

Although it is stated that NORSE is mostly seen in the adult age group and febrile infection-related epilepsy syndrome (FIRES) in childhood and young adults, the clinical diagnosis of FIRES should also be kept in mind in patients in the adult age group. Tektürk et al. (7) presented two patients in their thirties who had seizures of unknown cause resistant to treatment and who had a prodromal disease. These patients were diagnosed as having FIRES and the authors emphasized the importance of a ketogenic diet in the early period (7).

Nearly 200 rare causes of SE have been reported in the literature, and they can be divided into four categories: inflammatory and autoimmune encephalitis, rare infectious encephalitis, genetic disorders, and toxic disorders. The most common cause is autoimmune encephalitis $(1,8)$. The most frequently defined antibodies target the $\mathrm{N}$-methyl-D-aspartate receptor and the voltage-gated potassium channel (VGKC) complex (9).

Our 62-year-old female patient, who had no previous history of epilepsy, was followed up in our clinic due to SE and no autoimmune, metabolic, infective or paraneoplastic cause was found. In EEG, a slowing in background activity was observed, there was an increase in microproteins in the CSF, and no pathologic findings were found in neuroimaging.

Some studies suggested that immunotherapies (corticosteroid, iv immunoglobulin, plasmapheresis), especially in patients with cryptogenic NORSE, might have better outcomes, and this hypothesis is supported by the fact that NORSE is caused by autoimmune encephalitis in half of all patients. Delaying treatment may contribute to worse outcomes, such as in autoimmune and viral encephalitis $(10,11)$. In our patient, the early results of some of the tests performed for differential diagnosis and the early initiation of corticosteroid therapy with the pre-diagnosis of possible autoimmune encephalitis contributed to patient's good clinical outcome.

NORSE is a rare epileptic disorder that develops in previously healthy patients, but it has a high rate of mortality. Rare but treatable etiologies such as autoimmune encephalopathy can be identified in a very small number of patients as a result of extensive research. However, most patients have no known etiology. NORSE is a clinical picture that can result in good outcomes despite the resistance to treatment and long stay in ICUs, and it should be kept in mind that immunotherapy may be beneficial in the early period.

\section{Ethics}

Informed Consent: Written consent was obtained from the patient for the case report.

Peer-review: Externally and internally peer-reviewed.

\section{Authorship Contributions}

Surgical and Medical Practices: T.A., Y.G.A., Concept: T.A., B.A., Design: T.A., Data Collection or Processing: S.B., Analysis or Interpretation: T.A., S.B., B.A., Y.G.A., Literature Search: T.A., S.B., B.A., Y.G.A., Writing: T.A., S.B., B.A.

Conflict of Interest: No conflict of interest was declared by the authors.

Financial Disclosure: The authors declared that this study received no financial support.

\section{References}

1. Gaspard N, Foreman B, Alvarez V, et al. New-onset refractory status epilepticus:etiology, clinical features and outcome. Neurology 2015;85:1604-1613.

2. Gugger JJ, Husari K, Probasco JC, Mackenzie C. Cervenka. Newonset refractory status epilepticus:A retrospective cohort study. Seizure 2020;74:41-48

3. Serino D, Santarone ME, Caputo D, Fusco L. Febrile Infection-Related Epilepsy Syndrome (FIRES): Prevalence,impact and management strategies. Neuropsychiatr Dis Treat 2019;15:1897-1903.

4. Wilder-Smith EPV, Lim ECH, Teoh HL, et al. The NORSE (new-onset refractory status epilepticus) syndrome: defining a disease entity. Ann Acad Med Singap 2005;34;417-420.

5. Aurangzeb S, Prisco L, Adcock J, et al. New-onset super refractory status epilepticus: A case-series. Seizure 2020;75:174-184.

6. Sculier C, Gaspard N. New onset refractory status epilepticus (NORSE). Seizure 2019;68:72-78.

7. Tektürk P, Baykan B, Tüzün E. Febrile Infection Related Epilepsy Syndrome (FIRES) in adults imitating limbic encephalitis. J Neurol Sci 2015;43:243249.

8. Gaspard N. Unusual causes of status epilepticus. In: Drislane FW, Kaplan PW, (eds). Status epilepticus. Gewerbestrasse: Springer, Cham; 2018:87110.

9. Caputo D, Iorio R, Vigevano F, Fusco L. Febrile infection-related epilepsy syndrome (FIRES) with super-refractory status epilepticus revealing autoimmune encephalitis due to GABAAR antibodies. Eur J Paediatr Neurol 2018;22:182-185.

10. Gaspard N, Hirsch LJ, Sculier C, et al. New-onset refractory status epilepticus (NORSE) and febrile infection-related epilepsy syndrome (FIRES): state of the art and perspectives. Epilepsia 2018;59:745-752.

11. Titulaer MJ, McCracken L, Gabilondo I, et al. Treatment and prognostic factors for long-term outcome in patients with antiNMDA receptor encephalitis: an observational cohort study. Lancet Neurol 2013;12:157165. 